\title{
Study of filled dolines by using 3D stereo image processing and electrical resistivity imaging
}

\author{
Mateja Breg Valjavec* \\ Anton Melik Geographical Institute, Research Centre of the Slovenian Academy of Sciences and Arts
}

\begin{abstract}
This article deals with doline degradation due to uncontrolled waste dumping in the past in the Logatec Polje in Slovenia. It introduces a concept for determining 3D geometric characteristics (shape, depth, radius, area, and volume) of formerly concave landforms (i.e., recently filled dolines) by using a combination of two methods: (1) photogrammetric stereo processing of archival aerial photographs and (2) electrical resistivity imaging (ERI). To represent, visualize, and study the characteristics of the former surface morphology (i.e., the dolines before they were filled), a digital terrain model (DTM) for 1972 (DTM1972) was made using digital photogrammetry processing of five sequential archival aerial photographs (1972, () GURS). DTM1972 was visually and quantitatively compared with the DTM5 of the recent surface morfology (DTM5, () GURS, 2006) in order to define areas of manmade terrain differences. In general, a circular area with a higher terrain difference is an indicator of a filled doline. The calculated terrain differences also indicate the thickness of buried waste material. Three case-study dolines were selected for 3D geometric analysis and tested in the field using ERI. ERI was used to determine the genetic type of the original doline, to confirm that the buried material in the doline is actually waste, and to ascertain opportunities for further study of water pollution due to waste leakage. Based on a comparison among the ERI sections obtained using various electrode arrays, it was concluded that the basins are actually past concave landforms (i.e., dolines) filled with mixed waste material having the lowest resistivity value (bellow $100 \mathrm{ohm}-\mathrm{m}$ ), which differs measurably from the surrounding natural materials. The resistivity of hard stacked limestone is higher (above 1,000 ohm-m) than resistivity of cracked carbonate rocks with cracks filled with loamy clay sediments while in loamy alluvial sediment resistivity falls below $150 \mathrm{ohm}-\mathrm{m}$. Nevertheless, the contrast is sufficient to confirm the landfilled waste in all studied dolines. Based on the resistivity values of buried waste and the proximity of furniture and paper factories in the Logatec Polje, it is assumed that the dolines are filled with organic waste, mostly wood material mixed with other waste (municipal, construction, and demolition waste), which causes the variability of electrical resistivity.
\end{abstract}

Keywords: environmental geology; doline degradation; waste; stereo image processing; digital terrain model; electrical resistivity imaging

Received 6 March, 2013; Revised 19 November 2013; Accepted 17 December 2013

Citation: Breg Valjavec M. 2014. Study of filled dolines by using 3D stereo image processing and electrical resistivity imaging. International Journal of Speleology, 43 (1), 57-68. Tampa, FL (USA) ISSN 0392-6672 http://dx.doi.org/10.5038/1827-806X.43.1.6

\section{INTRODUCTION}

Dolines as a typical karst landform have been the sites of various traditional activities in Slovenia for centuries. These activities include arable farming, gardening, pasturing, and water supply. In the Karst region, for example, such features stand out with a density of as many as 150 dolines per $\mathrm{km}^{2}$, and in the karst Podgrad Lowland there are even 240 per $\mathrm{km}^{2}$ (Ciglič et al., 2012). However, features that reflect the effort and ingenuity of past generations (traditionally cultivated dolines and dry rock walls)

*mateja.breg@zrc-sazu.si are also disappearing (Urbanc et al., 2004; Mihevc, 2005; Ravbar \& Kovačič, 2013).

This article introduces one of the most critical karst areas in Slovenia, the Logatec Polje $\left(29 \mathrm{~km}^{2}\right)$. After the Second World War, the number of inhabitants in Logatec (the main urban center of the polje) grew rapidly, especially from 1970 to $2002(7,616$ inhabitants) (SURS, 2002). In the last fifty years, almost $77 \%$ of the dolines have vanished, at the rate of almost ten dolines per year (Breg, 2007). During industrialization and urbanization, karst depressions were filled with various waste, the largest share of which was household waste, as well as industrial and agricultural waste. Construction and demolition 
material was deposited only as the final covering (Bricelj, 1988). Many dolines were intentionally filled in and leveled with various waste material. For example, $12,000 \mathrm{~m}^{3}$ of embankment material (railway mounds from the former railway connection from Logatec to Idrija) was used in extensive agricultural meliorations in 1986 (Bricelj, 1988). Even today, farmers in the Pusto Polje (the northern part of the Logatec Polje) still fill alluvial subsidences with alluvium or inert waste. In combination with growing migration (to the vicinity of the capital, Ljubljana) and increased interest in new or better housing (cheaper than in the capital) in the Logatec Polje, filling dolines with construction waste continues. Some authors (Rathje, 1991; Hjelmar et al., 1995; Wall \& Zeiss, 1995; Kruempelback \& Ehrigh, 1999; Röhrs et al., 2000; Fourie \& Morris, 2004) suggest that waste may remain active for many decades and even for hundreds of years, depending on the physical conditions. Studies of such impacts usually examine water pollution (Kogovšek, 2011; Kogovšek \& Petrič, 2012). Water that percolates through the buried waste is saturated with acids and contaminants. It can penetrate faster and deeper into the vadose zone, which results in increasingly faster penetration of contaminants through the vadose zone (Kogovšek \& Petrič, 2012). In the final phase of such phenomena, which take many decades or longer, relatively rapid transfer of contaminants through the aquifer all the way to karst springs with minimal self-cleansing effects can be expected (Kogovšek, 2011).

The main problem in Slovenia is that filled dolines are mostly unrecognizable in the recent landscape because the filled area has become level with the surrounding terrain and is generally overgrown with vegetation or even built up. Their locations are unknown to the general public as well as to spatial planners, spatial development decision-makers, and unfortunately to water-supply companies as well. Not being able to determine the amount and type of waste also represents an unpredictable problem in karst hydrogeology and water supply. Thus the main goal is to study the locations of potentially filled dolines, to determine the genetic type of the original doline, to confirm that the buried material in the doline is actually waste, and to ascertain opportunities for further study of water pollution due to waste leakage. A 3D reconstruction was performed by focusing on dolines before they were filled. The first phase included generating a digital terrain model (DTM) of the former landscape from 1972 (DTM1972) to reconstruct the geometry, depth, and type of doline. Electrical resistivity imaging (ERI) was used as a control method to verify the results of the 3D analysis and to obtain additional data about the original landform and buried waste. The hypothesis is that the electrical resistivity of buried waste materials in former dolines differs from the electrical resistivity of the host rock (limestone or loamy sediment). The resistivity of buried material also differs regarding the type of waste (organic, mineral, construction and demolition, hazardous industrial sludges, etc.).

\section{MATERIALS AND METHODS}

\section{Study region and sites}

The Logatec Polje is an overflowing karst polje measuring $29 \mathrm{~km}^{2}$ (Mihevc, 1985). Most of this karst polje lies on dolomite, whereas limestone at the plateau elevation represents a 10 to $15 \mathrm{~m}$ higher rock cut terrace (Pleničar \& Buser, 1970; Fig. 1). The characteristics of dolines in the area studied are basically a result of hydrogeological and climatic conditions (annual precipitation is 1,900 $\mathrm{mm}$ ) and karst processes (solution, suffusion, and subsidence) that are continuously reshaping the terrain of the Logatec Polje and the surrounding plateau. The spatial distribution of the dolines in the Logatec Polje and on the plateau is conditioned by the lithological characteristics of the host rock. Thus, zones with different doline types may be distinguished (Fig. 1). The zone on limestone contains mostly solution dolines and collapse dolines, whereas the zone on dolomite contains shallow solution dolines. In addition, some dells can be found here (Komac, 2003, 2006). Dolines inside the polje are formed and are still forming in alluvial (Quaternary) deposits through suffusion processes; various authors refer to these as suffusion dolines (Ford and Williams, 2007), cover dolines (Sauro, 2003; Beck, 2003), alluvial dolines (Gams, 2003), or subsidences. Three filled dolines (Fig. 1) whose locations were also studied previously (Breg, 2007) were selected for detailed geometric reconstruction and electrical resistivity survey. Doline 1 (Fig. 2) lies in heavily karstified limestone bedrock (porous Lower Cretaceous strata; Pleničar \& Buser, 1970) and is a typical solution doline. The surrounding area is an industrially degraded area around the KLI company, which has manufactured wooden furniture since 1953. In its geological structure, Doline 2 (Fig. 3) is a suffusion doline located on a completely flat area of the polje with predominantly carbonate (crushed) rock in its foundation (dolomite or intermittent oolitic limestone and some noncarbonate Triassic slate) covered by Quaternary fluvial deposits with an average thickness of 3 to $4 \mathrm{~m}$ (Pleničar \& Buser, 1970). The area has a predominantly agriculture character, but also features long-term paper and cardboard production (the Valkarton company). Agriculture and modern agricultural melioration projects were oriented toward leveling the entire area. There are almost no preserved dolines in the area. The Doline 3 casestudy site (Fig. 4) is located on the southern part of the Logatec Polje, named also Brojsko polje. The doline lies in Quaternary alluvium (Pleničar \& Buser, 1970) and was traditionally used as a meadow until the 1970s (before filling) and is also used as such now (after filling). The area is characterized by the Logaščica River, which sinks into the karst underground nearby (at the Jačka Ponor). Due to the limited capacity of ponors (15 to $20 \mathrm{~m}^{3} / \mathrm{s}$ ), floods occur (Mihevc, 1985). Almost all of the dolines in the Brojsko Polje were completely artificially filled. 


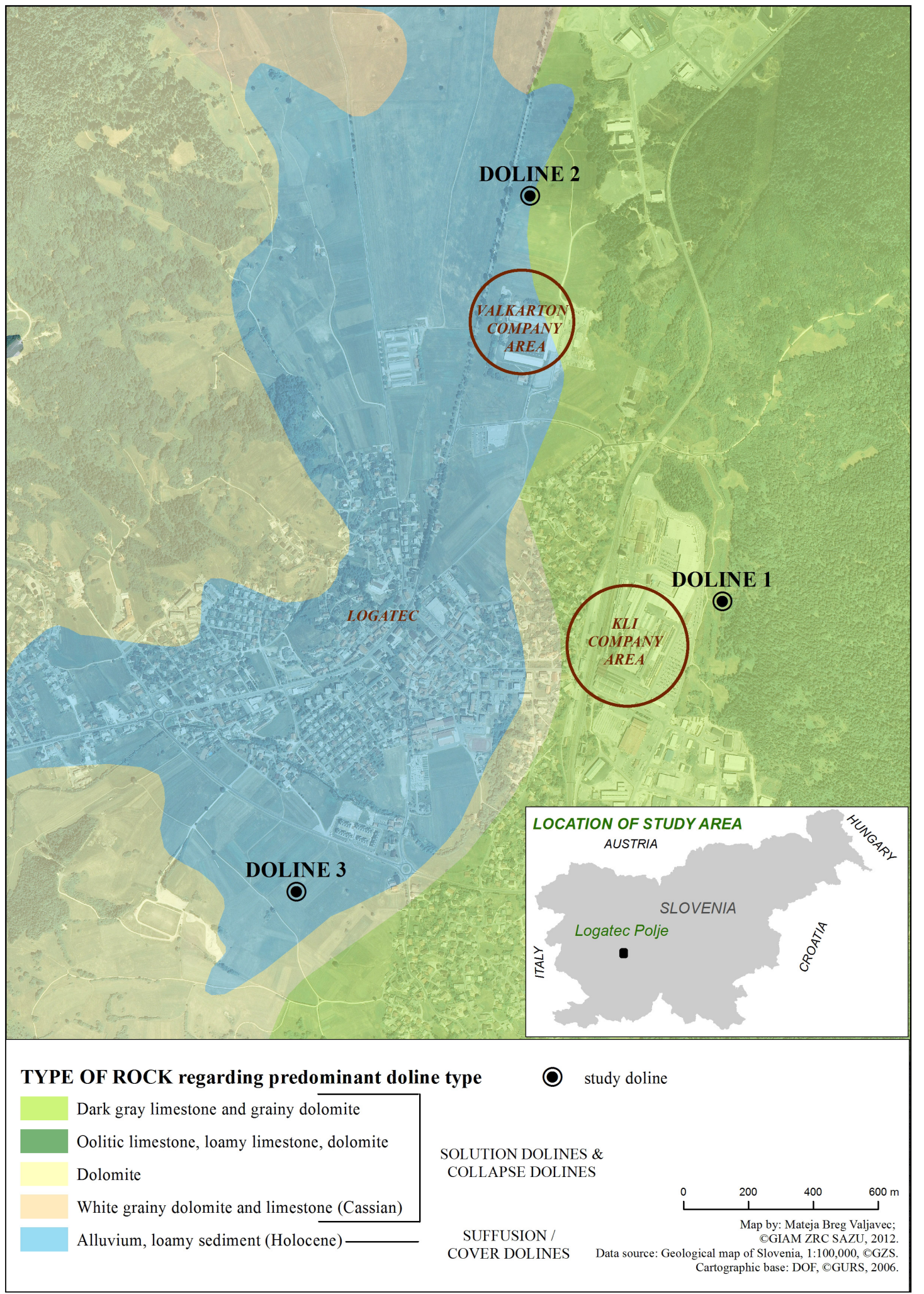

Fig. 1. The zonation of the Logatec Polje shows the predominant types of dolines in relation to the type of host rock. The locations of three case-study filled dolines (Dolines 1, 2, and 3) are marked in relation to the urban area and location of industrial plants (the Valkarton company and the KLI company) that produced the main share of industrial waste (organic waste, industrial sludge, etc.) in the Logatec Polje in the second half of the twentieth century.

\section{D stereo image processing}

Stereo image processing was applied to extract 3D geometry of the original dolines before they were filled with waste. Transforming the imagery into 3D geoinformatic data involves several processes commonly associated with digital photogrammetry. The most important result of photogrammetric methods (and extremely useful in spatial research) is DTM, a digital representation of heights of a specific area. Through various processing steps, 3D data can be automatically extracted and collected from archival aerial photographs. Stereo image processing is possible when a stereo effect is established. This means that at least two sequential aerial photographs (a stereo pair) must overlap to a satisfactory extent (usually $60 \%$ to $80 \%$ ) and the optical axes are not overly convergent (Triglav et al., 2000; Kraus, 2007). Selected archival aerial photographs from 1972 show the landscape of the Logatec Polje before major degradation processes and original doline landforms before they were filled. 


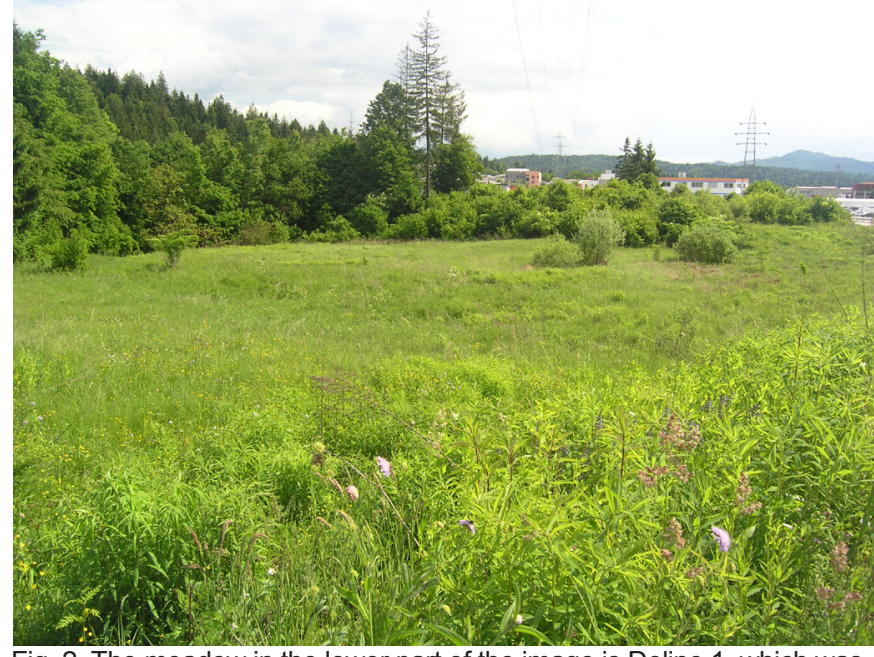

Fig. 2. The meadow in the lower part of the image is Doline 1, which was recently completely filled with waste and overgrown. The waste was poorly covered or not covered at all. A shallow layer of anthropogenic soil is developing above it with pioneer and invasive plants.

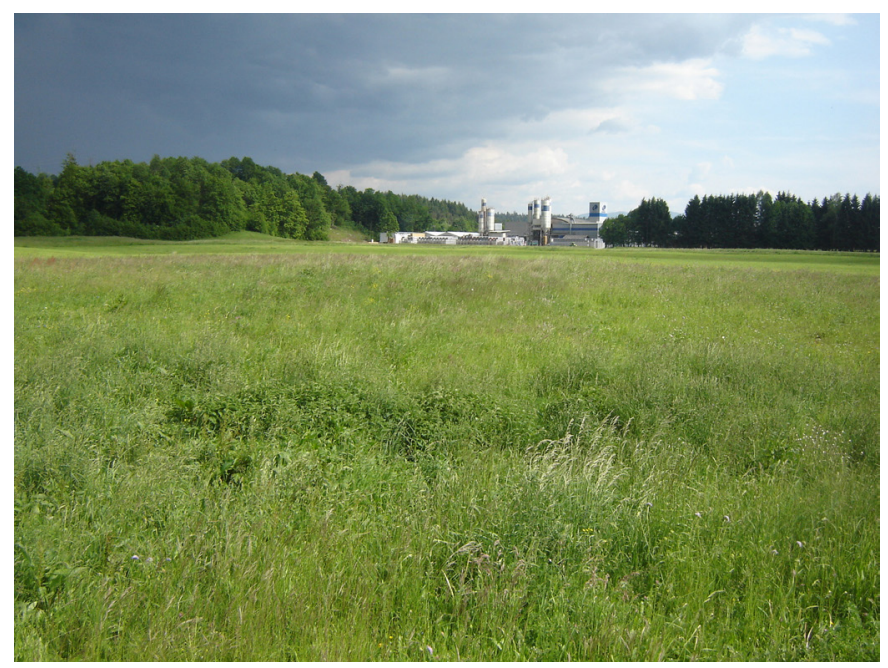

Fig. 3. Filled Doline 2 was a smaller doline in the northern part of Logatec Polje (i.e., the Pusto Polje), near the Valkarton paper and cardboard factory. The surface of the filled doline is slightly concave ( $<1 \mathrm{~m}$ deep) and vegetated with ruderal vegetation (orchard grass, Dactylis glomerata) and eutrophic vegetation (common nettle, Urtica dioica), which visually differ from typical meadow plants in the surroundings. (Photo: Tatjana Benčina Bedene, 2012)

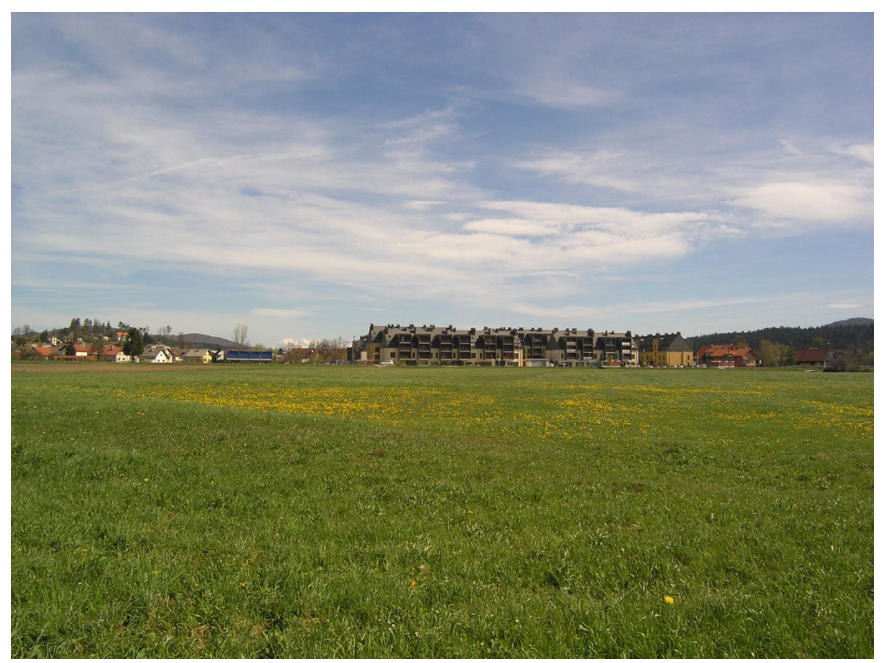

Fig. 4. Doline 3 is in the southern part of the Logatec Polje (i.e., the Brojsko Polje). Until recently it was completely unrecognized as concave karst landform. The surface above the buried waste is covered with dandelions (Taraxacum officinale) in the spring.
The DTM1972 (Fig. 5) generation was carried out for an area of five sequential aerial photographs of the same photographed strip, with at least $60 \%$ overlap of the selected photographs (C GURS, 1972).

The procedure includes determining the interior orientation (fiducial marks, focal length, and lens distortion), exterior orientation (ground control points and flight position of camera), and aero triangulation (Triglav et al., 2000; Kraus 2007). The main problem in stereo image processing of archival aerial photography is accurate triangulation due to lack of calibration reports (they were usually lost) that includes important interior orientation measures of the camera. The calibration report of the WILD RC-8 camera for the Special Aerial Survey (SAS) 1970 was used and the calibrated values for interior orientation were included in the sensor model. The DTM1972 for the study region was produced using Erdas Imagine 2011 software with LPS (Leica Photogrammetry Suite and Automatic Terrain Extraction module, (C) Erdas, 2011). DTM1972 was used to identify dolines in the former landscape and to obtain the 3D geometry of an individual doline.

\section{Multi-temporal DTM analysis}

Multi-temporal terrain analysis was performed to obtain data on doline depth corresponding to the thickness of buried waste in the doline. The stereo-processed DTM1972 of the former landscape and stereo-processed DTM5 of the more recent landscape from 2006 (C) GURS 2006) were visually and quantitatively compared. DTM5 is a detailed 5 $\mathrm{m}$ pixel presentation of today's surface morphology prepared for all of Slovenia with processing of aerial stereo photographs from 2006. Basic mathematical calculations (minus) were made to determine the manmade terrain differences in the period studied. The results are represented graphically as areas of " 1 to $5 \mathrm{~m}$ higher terrain" (Fig. 6, orange). Not only the quantitative difference but also visually recognized circular orange shapes of higher areas are the indicators of filled dolines.

\section{ERI MEASUREMENTS}

The geometry and the depth of three case-study dolines were evaluated in the field using ERI. ERI techniques are useful for exploring sediments and understanding surface morphology development (Komac, 2006). This methodology is widely used in researching doline issues, mostly oriented towards hydrological and geomorphological analyses, and less toward environmental studies and doline degradation. Previous applications of the ERI method in studying various karst landforms (collapse dolines, solution dolines, blind valleys, caves, etc.) in Slovenian karst showed that the resistivity value for carbonate rock exceeds $1,000 \mathrm{ohm}-\mathrm{m}$ and can reach very high values (30,000 ohm-m) (Stepišnik \& Mihevc, 2008; Stepišnik, 2008, 2011). For soil and weathered bedrock, the resistivity values are approximately between 200 and $1,000 \mathrm{ohm}-\mathrm{m}$, and loamy material has resistivity values lower than 150 ohm-m (Stepišnik \& Mihevc, 2008; Stepišnik, 2008, 2011). 


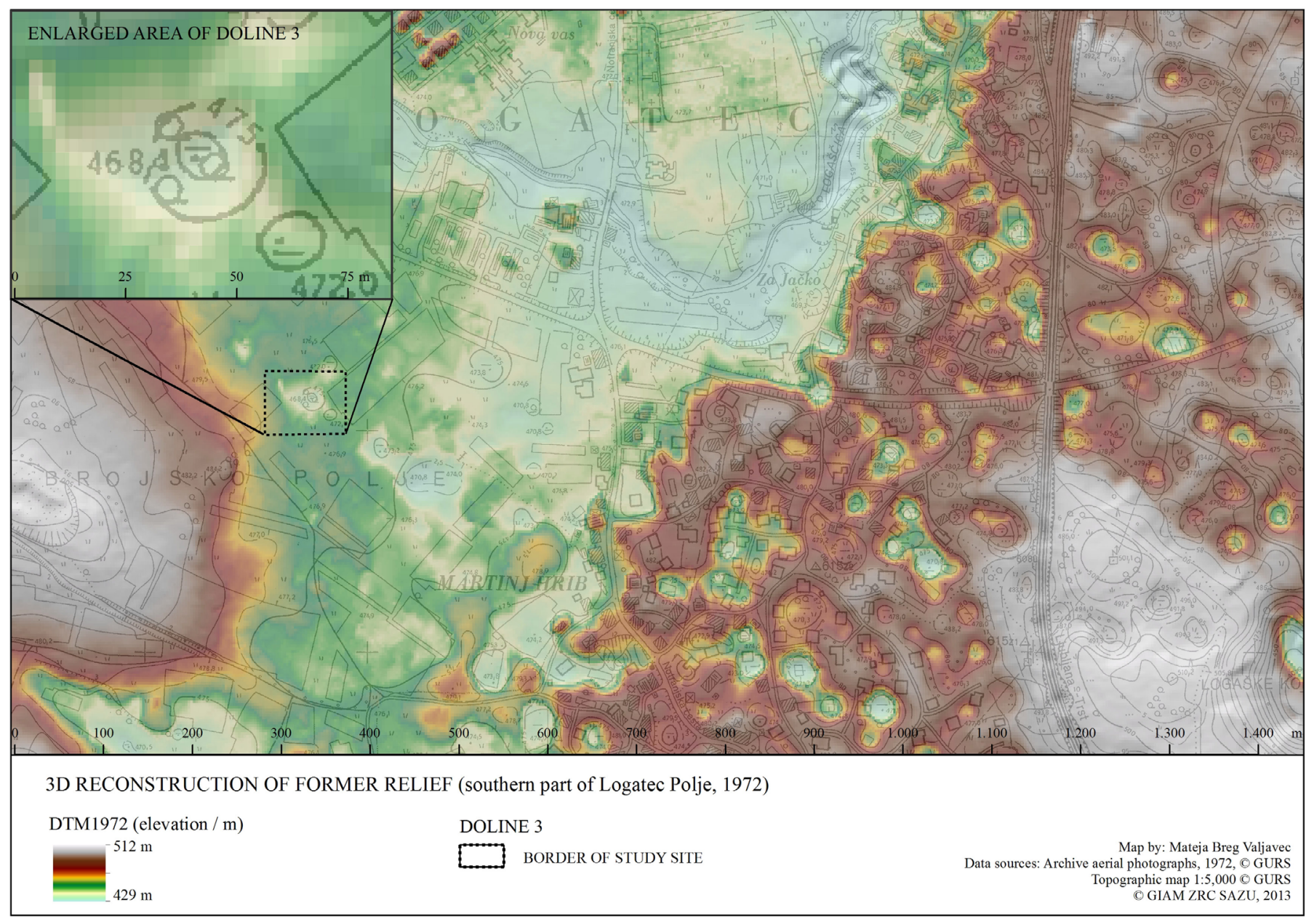

Fig. 5. DTM1972 is a 3D visual reconstruction of terrain in 1972. It is visualized in two different transparent layers (shaded terrain and hypsometric terrain) that are overlaid on a topographic map (1:5,000; elevation data from the same decade). The quality of DTM1972 enables visual and quantitative study of doline geometry before filling.

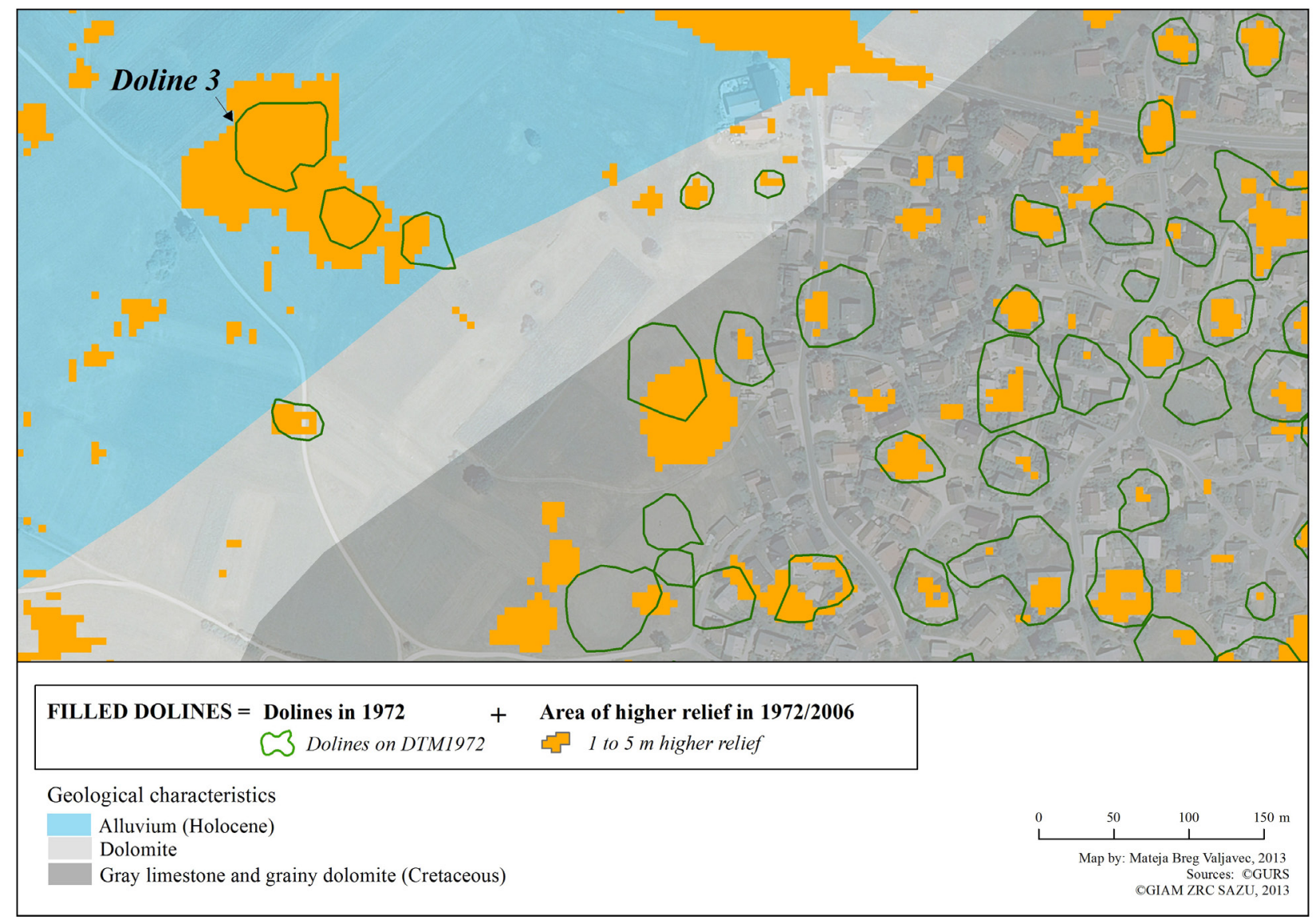

Fig. 6. Manmade terrain differences (orange) in the Logatec Polje between 1972 and 2006 generally indicate filled dolines. 
Buried waste is very heterogenic and it has a high primary porosity, many interconnected pore spaces, and consequently high conductivity and low resistivity. The resistivity value varies regarding the age and the stage of waste degradation (2.0-100 ohm-m). Georgaki et al. (2008) noted that a resistivity ranging from 0.21 to $4.00 \mathrm{ohm}-\mathrm{m}$ represents fresh organic waste saturated with leachate. When resistivity increases to between 4.00 and 20.00 ohm-m, the section represents fresh organic waste mixed with small amounts of cover material. Resistivity above $20.00 \mathrm{ohm}-\mathrm{m}$ and up to $50.00 \mathrm{ohm}-\mathrm{m}$ implies that the waste has a higher inorganic content or that organic waste is older (Georgaki et al., 2008). For a measurable electrical resistivity contrast between the waste material and the background rocks, deposits, or soils, electrical resistivity measurement should be a useful method for imaging the depth and geometry of dolines filled with waste.

This study used a Super Sting R1/IP (C) AGI Advanced Geosciences, Inc., Austin, TX) device with five cables of four electrodes to produce twodimensional (2D) models of the subsurface. They represent and visualize the resistivity changes both vertically and horizontally along the survey line. The measurements on the same section of surveyed dolines were repeated using two array types: Schlumberger and dipole-dipole. Generally, in cases in which horizontal structures were emphasized, the Schlumberger array was used, and in cases where vertical depth penetration and high resolution were of high importance, the dipole-dipole array was used. The use of different electrode arrays over karst formations was studied by Zhou et al. (2008), who concluded that the use of the dipole-dipole array is the most suitable method for assessing dolines or sinkholes in carbonate rocks. Komac (2006) used the Schlumberger array to study the genesis and shape of dells, whereas Ravbar \& Kovačič (2010) used the Wenner array. This study investigated the differences between the host rock and the buried waste with a Schlumberger array (72 measurements) and with a dipole-dipole array (117 measurements).

\section{RESULTS AND DISCUSSION}

\section{Doline 1}

Detailed 3D reconstruction of Doline 1 before it started being filled in 1972 (Fig. 7, upper left corner) showed that this is a case of longitudinally shaped doline with longer radius of $85 \mathrm{~m}$, a shorter radius

Table 1. The characteristics of electrical resistivity sections in casestudy dolines.

\begin{tabular}{|c|c|c|c|c|c|c|}
\hline $\begin{array}{c}\text { CASE- } \\
\text { STUDY } \\
\text { DOLINE }\end{array}$ & $\begin{array}{c}\text { DATE } \\
\text { of } \\
\text { measurement }\end{array}$ & HUMIDITY & $\begin{array}{c}\text { LENGTH } \\
\text { (meters) }\end{array}$ & $\begin{array}{c}\text { NUMBER } \\
\text { of } \\
\text { electrodes }\end{array}$ & $\begin{array}{c}\text { SPACING } \\
\text { between } \\
\text { electrodes } \\
\text { (meters) }\end{array}$ & $\begin{array}{c}\text { POSITION } \\
\text { of doline } \\
\text { and section } \\
\text { (figures) }\end{array}$ \\
\hline $\begin{array}{c}\text { DOLINE } \\
\mathbf{1}\end{array}$ & 26 Apr 2012 & $\begin{array}{c}\text { After } \\
\text { rainfall }\end{array}$ & 78 & 20 & 4 & $1,2,7,8,9$ \\
\hline $\begin{array}{c}\text { DOLINE } \\
\mathbf{2}\end{array}$ & $27 \mathrm{Apr} 2012$ & $\begin{array}{c}\text { After } \\
\text { rainfall }\end{array}$ & 56 & 20 & 3 & $\begin{array}{c}1,3,10, \\
11,12\end{array}$ \\
\hline $\begin{array}{c}\text { DOLINE } \\
\mathbf{3}\end{array}$ & $29 \mathrm{Mar} 2012$ & $\begin{array}{c}\text { Dry } \\
\text { season }\end{array}$ & 78 & 20 & 4 & $1,4,13,14$ \\
\hline
\end{tabular}

of $46 \mathrm{~m}$, a maximum depth of $9 \mathrm{~m}$, and an average area of 3,230 $\mathrm{m}^{2}$. Multi-temporal analysis of terrain (visual and automated) showed that recently, in 2006 (Fig. 7, right images), Doline 1 no longer had its original concave form but was leveled with the surrounding terrain.

The results of the electrical resistivity survey (Figs. 8 and 9) confirmed that Doline 1 is located in heavily karstified limestone bedrock (porous Lower Cretaceous strata) as determined on the geological map (Pleničar \& Buser, 1970) (Fig. 1) and also that this is a typical solution doline, obviously filled with allogenic material. Schlumberger and dipoledipole type arrays were applied on the same crosssection to obtain additional data on the 3D geometry of the doline, and to obtain better information on the waste type/structure and higher reliability of measurements. Regarding inversion images of both sections (Figs. 8 and 9), it was concluded that the basin is a doline 7 to $10 \mathrm{~m}$ deep. Dipole-dipole array measurements penetrated $2 \mathrm{~m}$ deeper than the Schlumberger array $(12.5 \mathrm{~m})$ and enabled a better insight into the doline shape and geomorphology. The buried material (Figs. 8 and 9, marked blue) has on average lower resistivity than all of the surrounding natural materials. Hard stacked limestone has the highest resistance (marked red). The resistivity of natural loamy deposits in the bottom is higher than resistivity of waste and is in accordance to reference values for loamy deposits (Stepišnik \& Mihevc 2008, Stepišnik, 2008, 2011). There is a thick soil or cover layer on top with a resistivity higher than waste and lower than limestone. The resistivity corresponds to the loamy soil, which may be saturated with water.

Regarding resistivity contrast, it is assumed that the concave landform is filled with waste material (marked blue) with low resistivity (below 60 ohm-m) due to higher porosity of waste material and to higher moisture (water, leachate) content. In line with the low resistivity values and proximity of the furniture factory, it is assumed that the doline is filled with organic waste, mostly wood material. Higher resistivity values of filled material indicate mineralized organic waste that can be mixed with municipal or construction waste. It may indicate that the waste material is gradually becoming rich in inorganic content or that the waste presents low leachate concentrations, which can be explained either by the mineralization of the organic fraction or primarily by the presence of greater amounts of cover material (soil). Considering the long time period (two decades or more) of waste landfilling, it can be assumed that the organic waste is older.

\section{Doline 2}

Original unfilled Doline 2 is a smaller doline (Fig. 10). Regarding the results of $3 \mathrm{D}$ reconstruction and multitemporal DTM analysis, the doline had a longer radius of $20 \mathrm{~m}$, a shorter radius of $15 \mathrm{~m}$, and a depth of $3 \mathrm{~m}$.

According to the geological map (Pleničar \& Buser, 1970) (Fig. 1), Doline 2 is on the border between hard stacked limestone (west) and loamy alluvium (east) deposited above carbonate rocks. These geological 


\begin{tabular}{|lr|}
\hline 3D RECONSTRUCTION OF DOLINE BEFORE AND AFTER FILLING & $\begin{array}{r}\text { Map by: Mateja Breg Valjavec } \\
\text { Data sources: GURS } \\
\text { O GIAM ZRC SAZU, 2013 }\end{array}$ \\
CASE STUDY: DOLINE 1 & CASE STUDY: DOLINE 1 \\
BEFORE FILLING: YEAR 1972 & AFTER FILLING: YEAR 2006
\end{tabular}
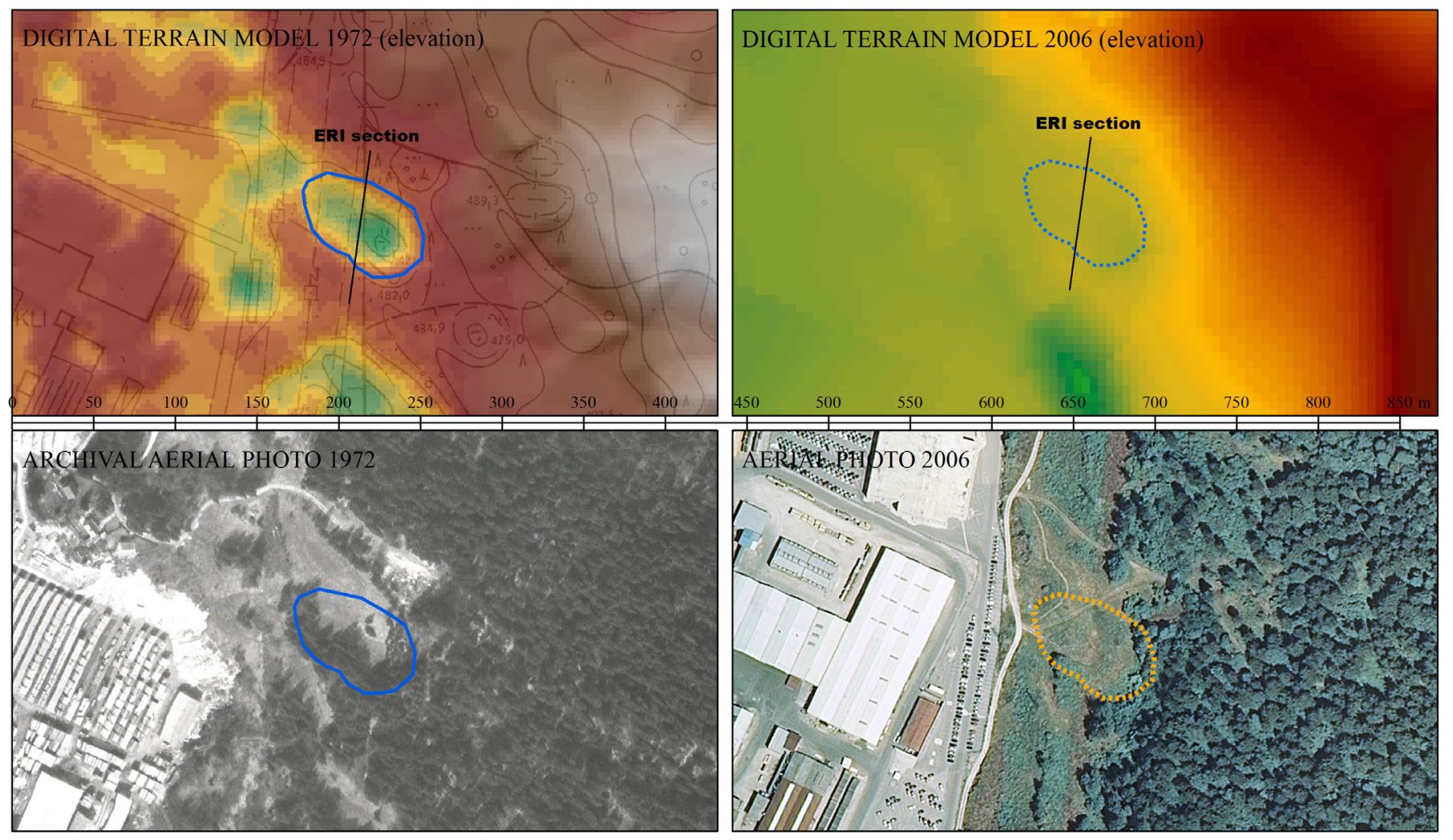

Fig. 7. Aerial photographs (bottom images)—as the input data for stereo image processing and generation of DTM (upper images)—enable 3D reconstruction of Doline 1 before and after it was filled. The ERI profile was positioned on potentially filled Doline 1 with the following profile characteristics: length $78 \mathrm{~m}$, number of electrodes 20 , distance between electrodes $4 \mathrm{~m}$.
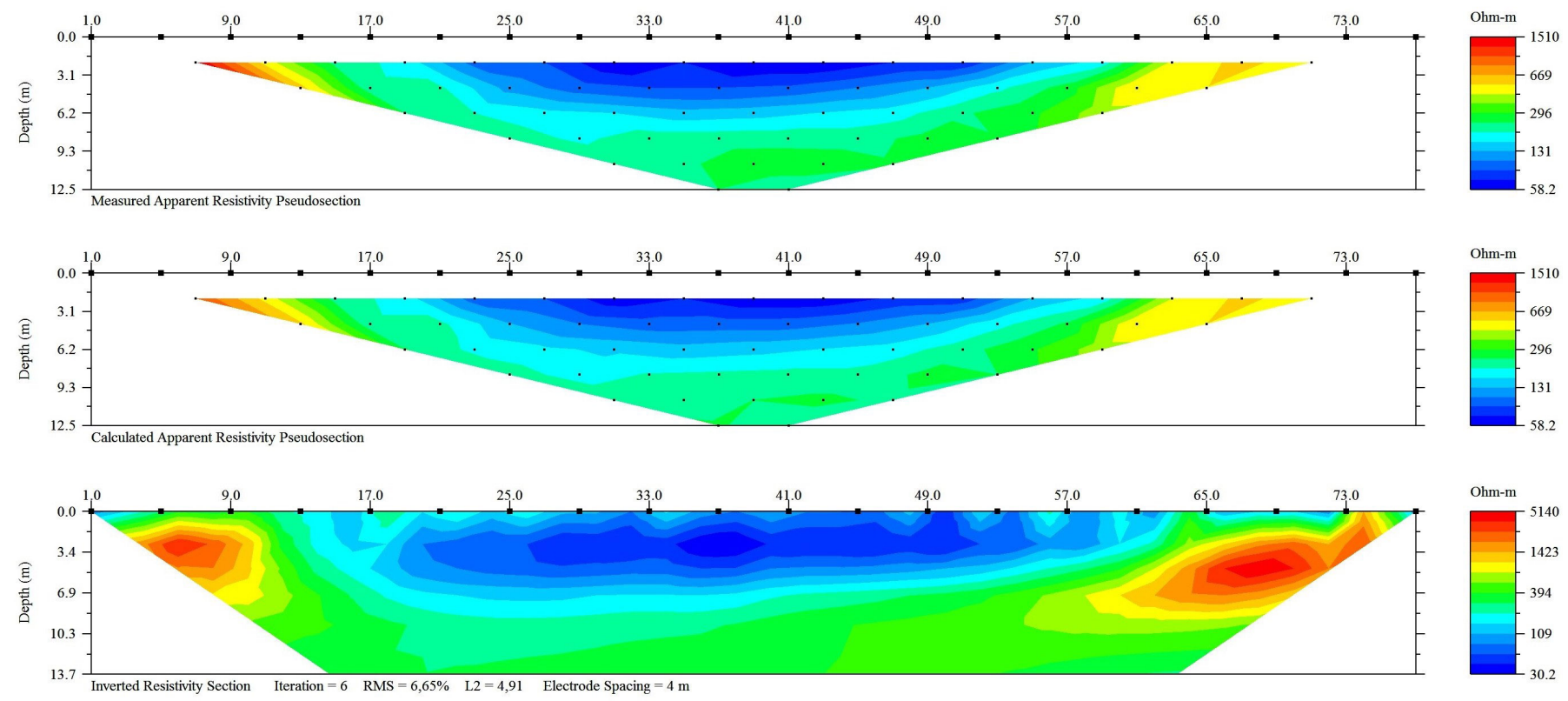

Fig. 8. Measured electrical resistivity section of Doline 1 applying a Schlumberger array.

predispositions were also confirmed with ERI profiles, shown in Figs. 11 and 12. The ERI method reveals that there are actually different limestones under the alluvium that have varying resistivity, not only hard stacked limestone. The stacked limestones have a greater resistivity than the cracked and fractured limestones with clay-filled loams because all of this has an effect on the rock moisture. After analyzing both 

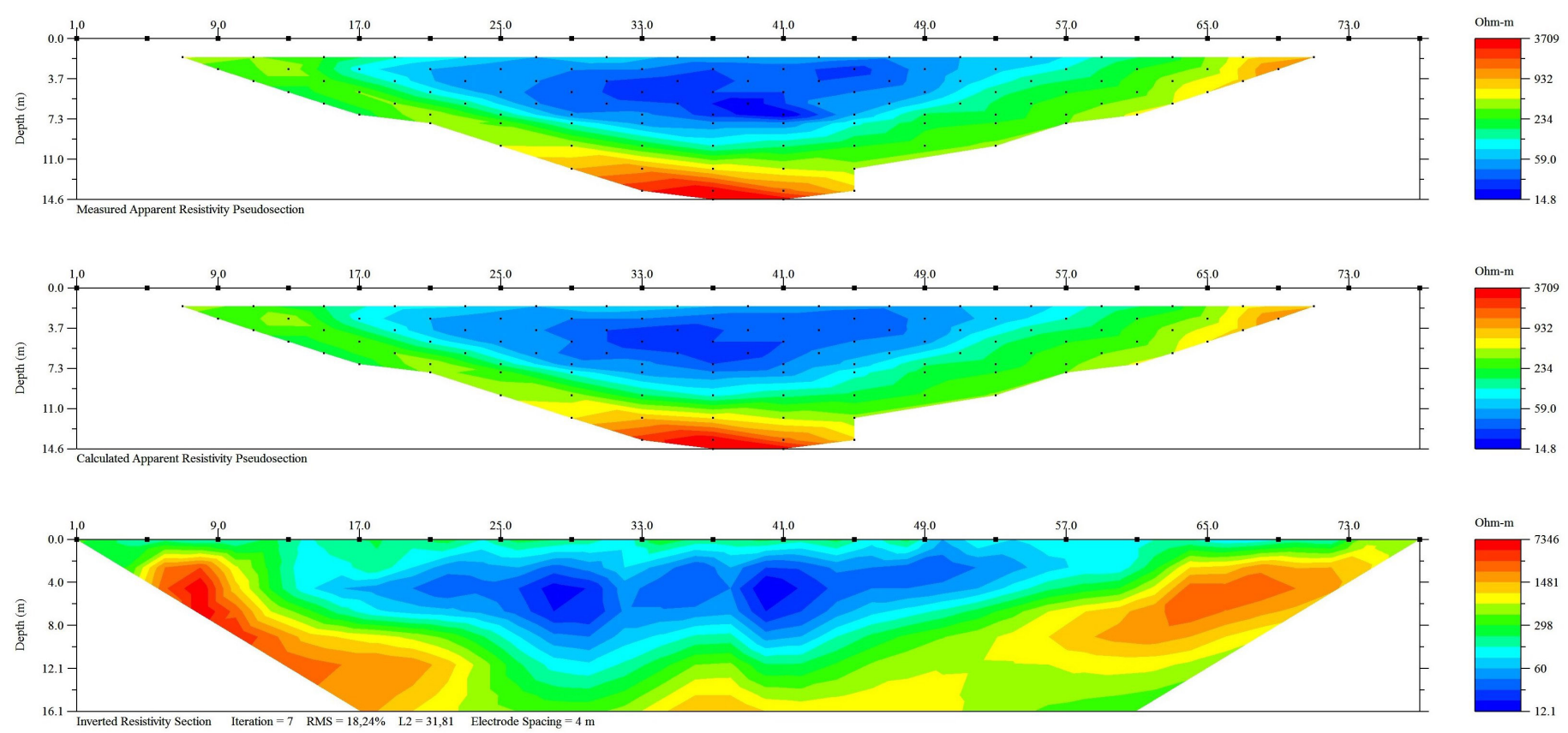

Fig. 9. Measured electrical resistivity section of Doline 1 applying a dipole-dipole array.

\begin{tabular}{|lc|}
\hline 3D RECONSTRUCTION OF DOLINE BEFORE AND AFTER FILLING & $\begin{array}{r}\text { Map by: Mateja Breg Valjavec } \\
\text { Data sources: GUSR } \\
\text { O GIAM ZRC SAZU, 2013 }\end{array}$ \\
CASE STUDY: DOLINE 3 & CASE STUDY: DOLINE 3 \\
BEFORE FILLING: YEAR 1972 & AFTER FILLING: YEAR 2006
\end{tabular}

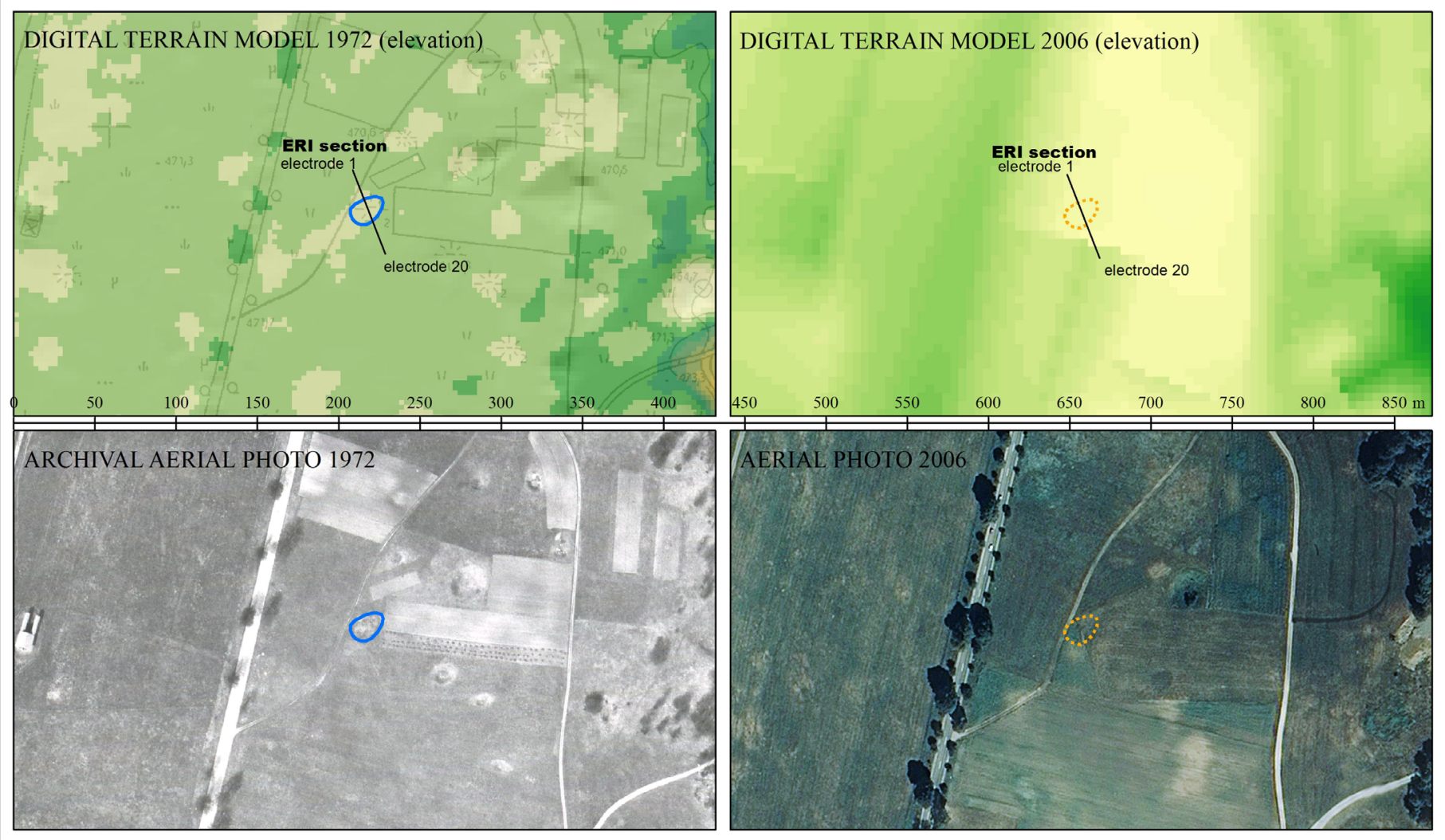

Fig. 10. Aerial photography (bottom image) and DTM (upper images) enabled visual and 3D reconstruction of Doline 2 before and after filling.

sections, it was concluded that suffusion Doline 2 lies in the contact between cracked limestone and loamy deposits. The blue color in the middle indicates a 2 to $3 \mathrm{~m}$ layer of buried waste with the lowest resistivity that differs from the surrounding material, comprised of loamy alluvium and fractured limestone filled with loam. It can be assumed that the organic waste from industry in combination with organic municipal waste prevails and was mixed and covered with loamy soils during agricultural melioration in the 1980s.

The dipole-dipole section (Fig. 12) also shows an interesting funnel-shaped doline filled with waste (blue), which points to leaking material seeping into the lower-lying soil or sediment layer (green) and deeper 


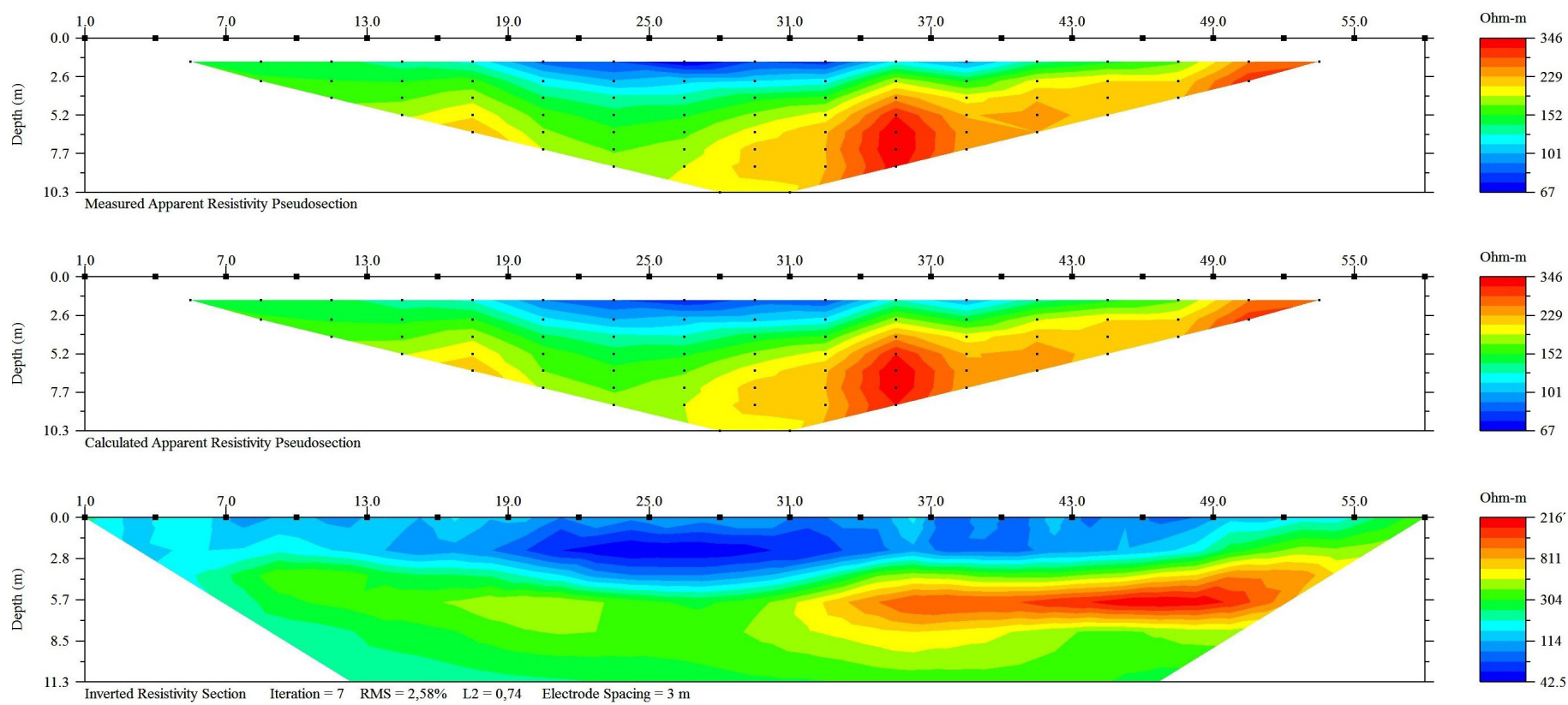

Fig. 11. Electrical resistivity section through Doline 2, using a Schlumberger array.
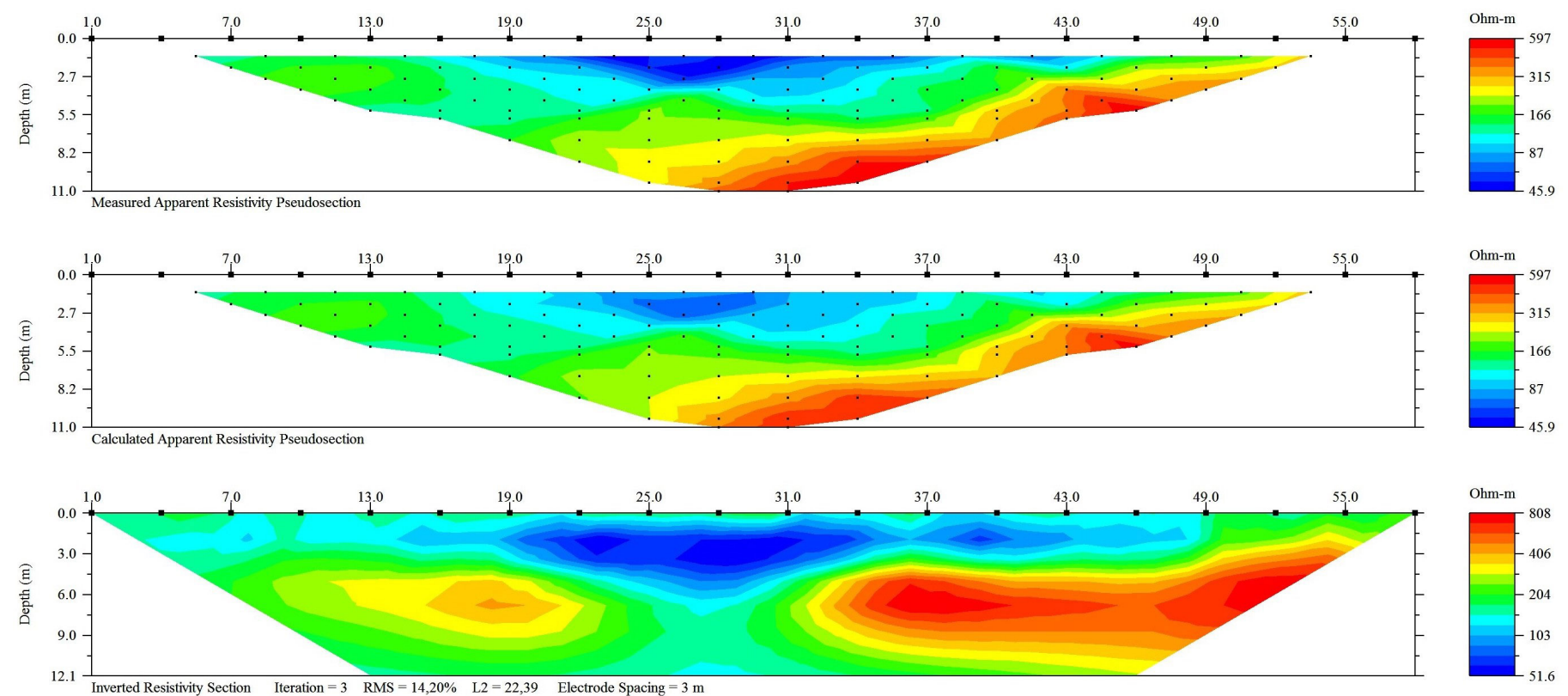

Fig. 12. Electrical resistivity section of Doline 2 , using a dipole-dipole array.

into the karst underground, correlating with recent suffusion processes. Because the measurements were made after heavy rainfalls, increased water drainage through waste into the karst underground could have been expected. The data inversion was repeated several times using different input parameters in order to confirm that this was a case of leakage. Based on the results obtained, this thesis cannot be entirely confirmed because the plume did not show the same intensity in every case. In order to unequivocally prove this thesis, it would be necessary to repeat the measurements in different time periods, after heavy rainfall and testing different arrays, as well as in a dry period to determine the landform characteristics. Regarding the type of doline and the high annual precipitation $(1,900 \mathrm{~mm})$ the suffusion processes are still very active in reshaping the terrain of the polje. The plume may be an indicator for the direction of the suffusion processes. In addition to natural sediments, residuals of mixed waste are also transmitted into the karst underground.

\section{Doline 3}

The visual comparison of aerial photographs from different times (1972 and 2006; Fig. 13) indicates some important geometric changes in the landscape of Doline 3 and some elements of land degradation. In the black-and-white aerial photography from 1972, case-study Doline 3 can be interpreted as a concave circular landform on the basis of darker colors (shadows) in the bottom of the doline. In the color photograph from 2006, the doline is recognizable as a brighter greenish-gray area that coincides with circular areas and indicates a drier surface (construction and demolition waste) than the surrounding loamy alluvium. The location and shape 
of the original Doline 3 can be successfully recognized in the field in vegetation patterns, especially in the spring (Fig. 4). Blossoming dandelion (Taraxacum officinale) is concentrated on the circular area of the filled doline, reflecting the ground (soil) differences on the area of the filled doline in comparison to surrounding meadow vegetation. Case-study Doline 3 is recognizable in terrain from 1972 as a concave landform and as a flat surface in terrain from 2006 (Fig. 13). The original unfilled Doline 3 had a longer radius of $30 \mathrm{~m}$ and a shorter radius of $25 \mathrm{~m}$, as determined with $3 \mathrm{D}$ reconstruction. Based on the results of multi-temporal DTM analysis, the depth of the doline is up to $5 \mathrm{~m}$.

The ERI sections (Figs. 14 and 15) feature the basin in rocks with higher ground resistivity but do not express extreme contrast with the host rock. These may be fractured and loam-filled limestone or dolomites, as in the case of Doline 2, or loam sediment saturated with water. The borders cannot be precisely determined due to the small resistivity contrast. The low-resistivity (waste) material was shown to be lying in the middle, just beneath the surface, with a developed anthropogenic soil layer on top by testing two array methods: Schlumberger and dipole-dipole. There are two large clusters of waste inside the doline (blue) with slight breaks with a slightly higher resistance, which may indicate different waste. The sectional profile demonstrates that this is actually one large doline marked on Fig. 15. The measured depth of the basin is approximately $6 \mathrm{~m}$, according to the level of gradient from a lower to higher ground resistance.

\section{CONCLUSIONS}

Stereo image processing is a successful method for the geomorphological study of filled dolines. Some basic characteristics of original doline landforms before they were filled were detected: shape, depth, and type of doline. Using 3D reconstruction of former surface morphology and multi-temporal terrain analysis, based on DTM1972 and DTM5 (2006), all three dolines were confirmed as concave objects in 1972 and as a flat surface in 2006. The study shows that visual analysis of aerial photographs alone is not sufficient for recognizing all dolines and should be complemented with stereo image processing. Doline 1 cannot be precisely determined in black-and-white archival aerial photographs (Fig. 7, bottom left corner) because it is surrounded by high trees that prevent visual recognition of the circular shape and concaveness. In contrast, both suffusion dolines (Dolines 2 and 3 ) are evidentially smaller, shallower landforms inside agricultural land (a meadow and tilled field) and relatively well recognizable in the aerial photographs.

ERI is a helpful method for the geomorphological study of filled dolines in combination with

\begin{tabular}{|lr|}
\hline 3D RECONSTRUCTION OF DOLINE BEFORE AND AFTER FILLING & $\begin{array}{r}\text { Map by: Mateja Breg Valjavec } \\
\text { Data sources: GURS } \\
\text { O GIAM ZRC SAZU, 2013 }\end{array}$ \\
CASE STUDY: DOLINE 3 & CASE STUDY: DOLINE 3 \\
BEFORE FILLING: YEAR 1972 & AFTER FILLING: YEAR 2006 \\
\hline
\end{tabular}
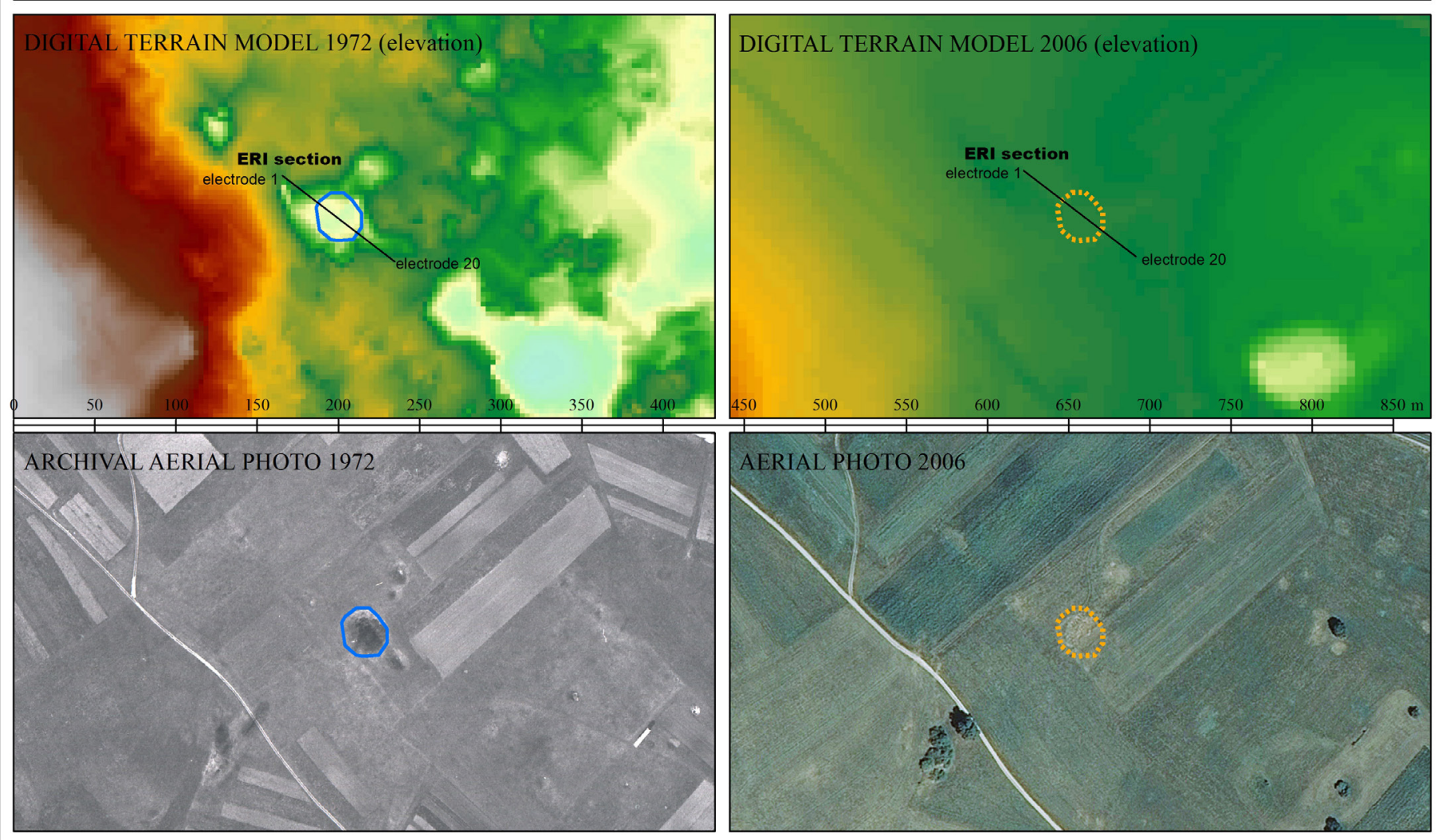

Fig. 13. Electrical resistivity was measured on potentially filled Doline 3, with the following profile characteristics: length: $78 \mathrm{~m}$, number of electrodes: 20, distance between electrodes: $4 \mathrm{~m}$ 

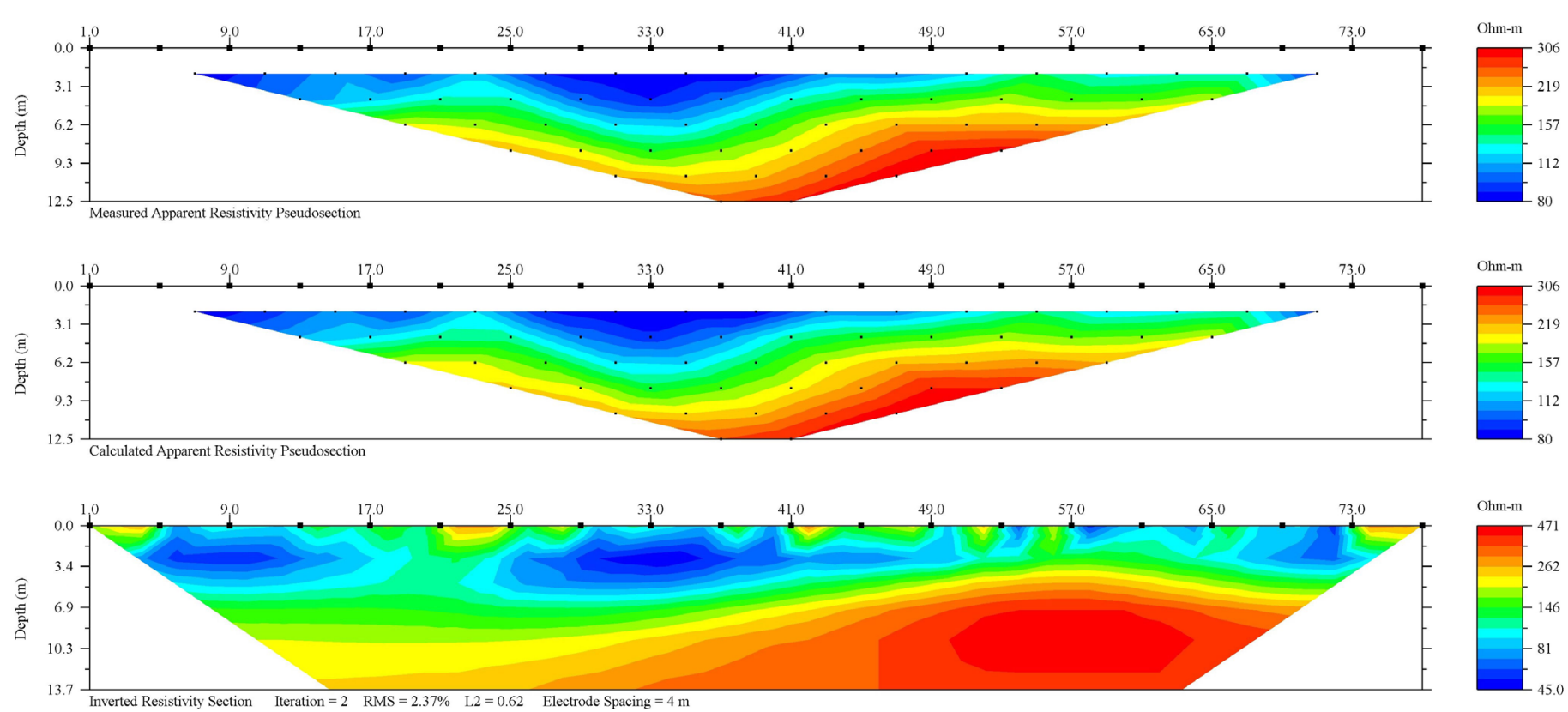

Fig. 14. Electrical resistivity section of Doline 3, using a dipole-dipole array.

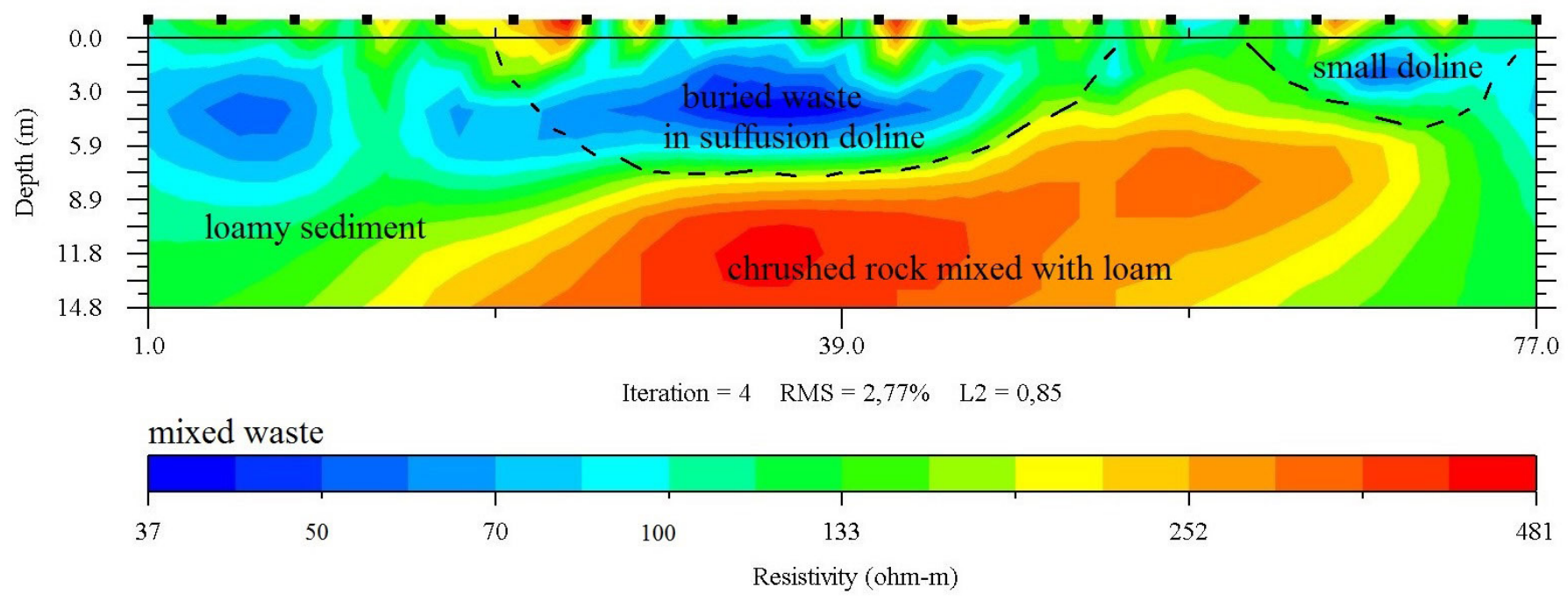

Fig. 15. Electrical resistivity section of Doline 3, using a dipole-dipole array.

stereo image processing. Using ERI, some basic characteristics of original doline landforms before they were filled were detected: shape, depth, and type of doline. This offers reliable results in combination with stereo image processing and $3 \mathrm{D}$ reconstruction of the former surface morphology. Dipole-dipole array measurements penetrated deeper than those using a Schlumberger array and enabled better insight into doline shape and geomorphology. In the case of solution dolines (Doline 1), a high contrast in resistivity of host rocks and buried waste was measured, enabling determination of the landform boundary (geomorphology) between the bedrock and the buried waste, doline depth, and the thickness of bottom loamy sediment and manmade cover layer. Thus it can be concluded that ERI is successful for the study of solution dolines. Suffusion dolines (Dolines 2 and 3), in comparison to solution dolines, are smaller, shallower, and formed in unconsolidated sediments, where the resistance of host rock is generally less different from the unconsolidated buried waste. The small size and shallowness of suffusion dolines and fuzzy resistivity contrast between waste and rock make it difficult to accurately determine the shape and depth of suffusion dolines. Nevertheless, the contrast is sufficient to confirm the landfilled waste.

It can be concluded that ERI is a successful method for the environmental study of filled dolines. It is suitable for imaging the depth and geometry of dolines filled with waste, where there is a measurable electrical resistivity contrast between the waste material and the background rocks, deposits, or soils. The resistivity of waste in all of the case studies is significantly lower than the surrounding carbonate rock or even loamy alluvium. Higher resistivity of waste implies that the waste has a higher inorganic content or that the proportion of organic waste is either very low or the organic waste is very old (i.e., mineralized). Regarding the low resistivity values of buried waste, proximity of an urban area, and two factories mostly dealing with organic raw materials (furniture, paper, and cardboard production using 
wood as a raw material), the most likely conclusion is that the dolines were filled with organic industrial and mixed municipal waste. The weakness of ERI is that it does not make it possible to determine the waste age and stage of biodegradation. However, it can be assumed that older waste is more compact, with a smaller primary porosity than new waste. Consequently, old waste has higher resistivity values and less intense contrast with host materials.

All three basic conclusions can be the basis for further geophysical studies focusing on the recognition and visualization of hydrogeological processes that enable transport of landfill leachates from buried waste into the karst underground.

\section{ACKNOWLEDGMENTS}

Thanks to Tatjana Benčina Bedene, Petra Gostinčar and Manja Žebre for their help and their assistance with the fieldwork.

\section{REFERENCES}

Beck B.F., 2003 - Sinkholes and the engineering and the environmental impacts of karst. Geotechnical Special Publication, 122: 737.

http://dx.doi.org/10.1061/9780784406984

Breg M., 2007 - Degradation of dolines on Logatec Polje (Slovenia). Acta carsologica, 36: 223-231.

Breg Valjavec M., 2007 - Environmental aspects of dolines protection in Slovenia. Dela, 28: 43-57.

Breg Valjavec M., 2010 - The digital elevation model of the past landscape: the case study Logatec Polje (year 1972). In: Perko D., Zorn M., Krevs M., Repe B., Kokalj Ž., Podobnikar T. (Eds) - Geografski informacijski sistemi v Sloveniji 2009-2010: 65-78.

Bricelj M., 1988 - Popis odlagališc odpadkov in pokrajinskoekološki vidiki izbora alternativnih lokacij za urejeno odlaganje smeti $v$ obcini Logatec, Ljubljana, 38 p.

Ciglič R., Hrvatin M., Komac B. \& Perko D., 2012 Karst as a criterion for defining areas less suitable for agriculture. Acta geographica Slovenica, 52: 61-98. http://dx.doi.org/10.3986/AGS52103

Ford D. \& Williams P.W., 2007 - Karst hydrology and geomorphology, Chichester, $561 \mathrm{p}$.

Fourie A.B. \& Morris J.W.F., 2004 - Measured gas emissions from four landfills in South Africa and some implications for landfill design and methane recovery in semi-arid climates. Waste Management and Research, 22: 440-53.

http://dx.doi.org/10.1177/0734242X04048332

Gams I., 2003 - Kras v Sloveniji v prostoru in času, Ljubljana, $516 \mathrm{p}$.

Georgaki I., Soupios P., Sakkas N., Ververidis F., Trantas E., Vallianatos F. \& Manios T., 2008 - Evaluating the use of electrical resistivity imaging technique for improving $\mathrm{CH}_{4}$ and $\mathrm{CO}_{2}$ emission rate estimations in landfills. Science of the Total Environment, 389: 522-531. http://dx.doi.org/10.1016/j.scitotenv.2007.08.033

Hjelmar O., Johannsen L.M., Knox K., Ehrig H.J., Flyvbjerg J., Winther P. \& Christensen T.H., 1995 Composition and management of leachate from landfills within the EU. Proceedings Sardinia 95, 1: 243-262.

Kogovšek J., 2011 - Impact of chlorides, nitrates, sulfates and phosphates on increased limestone dissolution in the karst vadose zone (Postojna Cave, Slovenia). Acta carsologica, 40: 319-327.
Kogovšek J., \& Petrič M., 2012 - Increase of vulnerability of karst aquifers due to leakage from landfills. Environmental Earth Sciences.

Komac B., 2003 - Dolomite relief in the Žibrše Hills. Acta geographica Slovenica, 43: 7-31. http:/ / dx.doi.org/10.3986/AGS43201

Komac B., 2006 - Electrical resistivity measurements as a tool for ascertaining material characteristics in dolomite areas. Geographical Bulletin, 78: 65-76.

Kraus K., 2007 - Photogrammetry: geometry from images and laser scans. Berlin, New York: 459 p.

Kruempelbeck I., \& Ehlrig H.J., 1999 - Long-term behaviour of municipal solid waste landfills in Germany. Proceedings Sardinia 99, 1: 27-36.

Mihevc A., 1985 - Geomorphologic map of Logatec Rovte. Acta Carsologica, 14/15: 207-218.

Mihevc A., 2005 - Dry walls and transformed dolines: anthropogenic influence on the surface of the Kras in the area of Divača, Račice and Volčji Grad. In Mihevc A. (Eds): Kras: Water and life in a rocky landscape, 57-71.

Pleničar M. \& Buser S., 1970. Basic Geological map of SFRY. Interpretation of Map L33 - 77 / Osnovna geološka karta SFRJ. Tolmač za list Postojna, L33 - 77.

Rathje W., 1991 - Once and future landfills. National Geographic, 179:116-134.

Ravbar N. \& Kovačič G., 2010 - Characterisation of karst areas using multiple geo-science techniques: a case study from SW Slovenia. Acta carsologica, 39: 51-60.

Ravbar N. \& Kovačič G., 2013 - Analysis of human induced changes in a karst landscape: the filling of dolines in the Kras plateau, Slovenia. Science of total environment, 447: 143-151.

Röhrs L.H., Fourie A.B. \& Blight G.E., 2000 - Is 30 years an appropriate after-care period for municipal landfills? Proceedings "WasteCon 2000," Somerset West, South Africa, 2: 369-378.

Sauro U., 2003 - Dolines and sinkholes: Aspects of evolution and problems of classification. Acta carsologica, 32: 41-52.

Stepišnik U., 2008 - The application of electrical resistivity imaging in collapse doline floors: Divaca Karst, Slovenia. Studia Geomorphologica Carpatho Balcanica, 42: 41-56.

Stepišnik U. \& Mihevc A., 2008 - Investigation of structure of various surface karst formations in limestone and dolomite bedrock with application of the Electrical Resistivity Imaging. Acta carsologica, 37: 133-140.

Stepišnik U., 2011 - Sediments in collapse dolines on the Kras Plateau. Acta geographica Slovenica, 51: 233252. http://dx.doi.org/10.3986/AGS51201

Triglav M., Kosmatin Fras M. \& Gvozdanovič T., 2000 - Monitoring of glacier surfaces with photogrammetry, a case study of the Triglav glacier. Acta geographica Slovenica, 40: 7-30.

Urbanc M., Printsmann A., Palang H., Skowronek E., Woloszyn W. \& Konkoly Gyuró E. 2004 - Comprehension of rapidly transforming landscapes of Central and Eastern Europe in the 20th century. Acta geographica Slovenica, 44: 101-131. http://dx.doi.org/10.3986/AGS44204

Wall D.K. \& Zeiss C., 1995 - Municipal landfill biodegradation and settlement. Journal of Environmental Engineering, 121: 214-223. http://dx.doi.org/10.1061/(ASCE)0733-9372(1995)121:3(214)

Zhou W., Beck B. \& Adams A., 2008 - Effective electrode array in mapping karst hazards in electrical resistivity tomography. Environmental Geology, 42: 922-928. http:/ / dx.doi.org/10.1007/s00254-002-0594-Z 